\title{
NPM1/RARA Short Fusion Protein
}

National Cancer Institute

\section{Source}

National Cancer Institute. NPM1/RARA Short Fusion Protein. NCI Thesaurus. Code C101065.

A fusion protein (520 aa, 57 kDa) encoded by the NPM1/RARA short fusion gene. This protein is comprised of the $\mathrm{N}$-terminus of the nucleophosmin protein fused to the DNAbinding domain, ligand binding domain and coactivator recog nition site from the retinoic acid receptor alpha protein. 